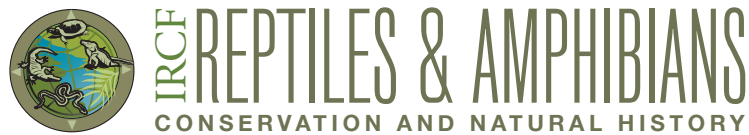

\section{Distribution of Invasive Red-eared Sliders, Trachemys scripta (Testudines: Emydidae) in the Wetlands of Gujarat State, India}

Raju Vyas

1-Sashwat Apartment, Anand Nager, BPC Haveli Road, Nr. Splatter Studio, Alakapuri, Vadodara-390007, Gujarat, India (razoovyas@hotmail.com)

"C xotic," "alien," or "non-native" describes those species Coccurring outside their native or current ranges. When an exotic species becomes established (or "naturalized"), its population grows, and it has a deleterious impact on native ecosystems, it is termed "invasive" (IUCN 2019). The effects and consequences of "invasive alien species" (IAS) were largely overlooked as a research subject until the General Assembly of the Scientific Committee on Problems of the Environment (SCOPE) began

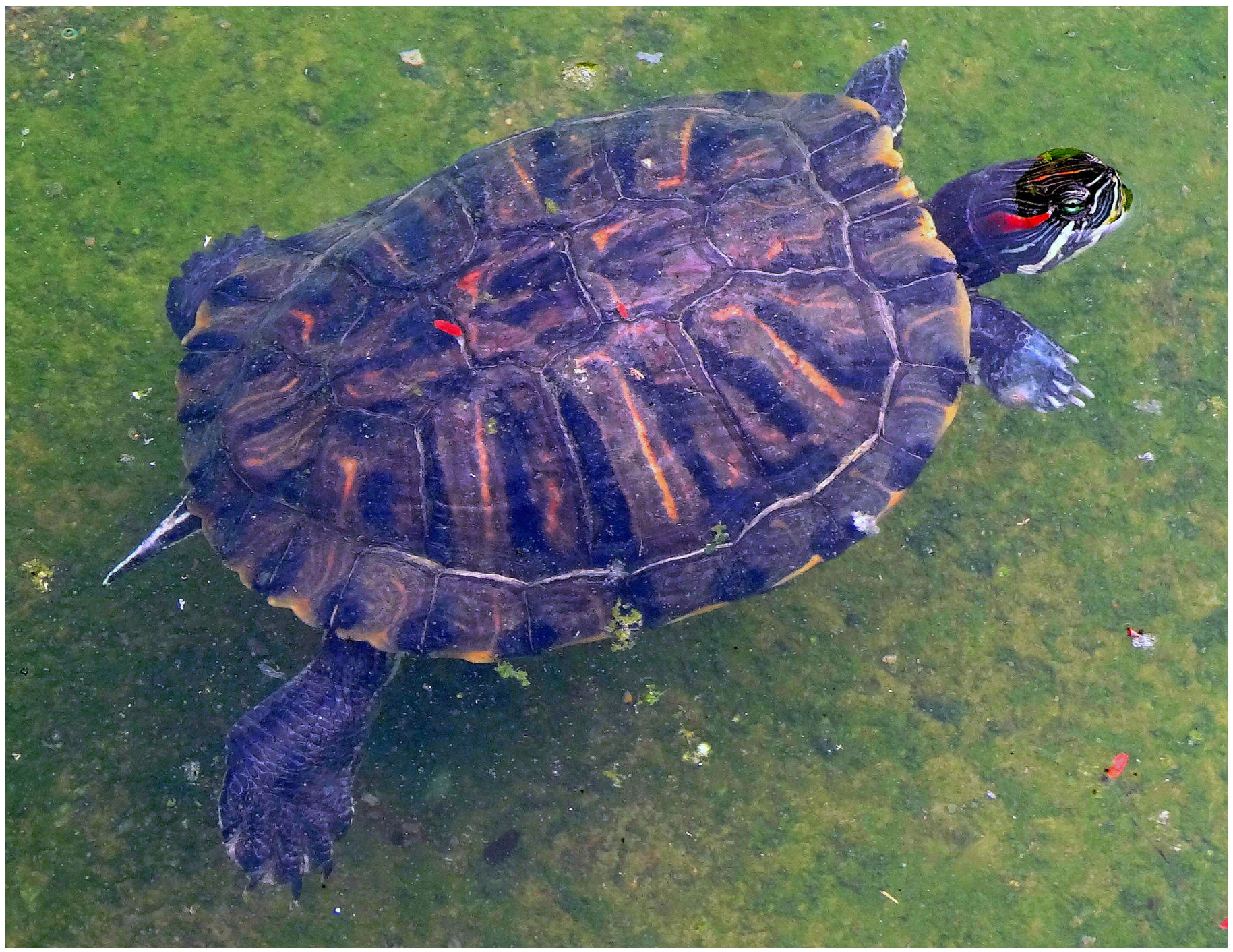

Fig. 1. The Red-eared Slider (Trachemys scripta elegans) is the most widely distributed invasive turtle species in the world. This individual is in captivity at the Sayang Bagi Zoo in Vadodara, Gujarat, India. Photograph by the author. 
to address the ecology of biological invasions in 1982 (Drake et al. 1989), leading to the subject being properly discussed and addressed properly in India for the first time (Ramkrishnan 1991). Nevertheless, India currently has no exclusive legislation or any strong policies to deal with IAS (Pande and Arora 2014). Every year many exotics are imported into India - and one of the most popular is a turtle, the Red-eared Slider, Trachemys scripta elegans (Fig. 1; Ramsay et al. 2007).

Red-Eared Sliders represent one of three currently recognized subspecies of the Pond Slider (T. scripta; e.g., Ernst et al. 1994). The native range of T. scripta is the eastern United States (e.g., Ernst and Lovich 2009; Rhodin et al. 2009; Powell et al. 2016) but due to its popularity in the pet trade, T. scripta elegans is now the most widely introduced turtle species in the world (e.g., Ng et al. 2005; Ramsay et al. 2007) and is considered one of the world's 100 worst invasive alien species (Lowe 2004). Populations are established on every continent except Antarctica (e.g., Lever 2003; Ramsay et al. 2007; Kraus 2009) and those naturalized populations have been reported from at least 73 countries or overseas territories in Europe, Africa, Asia, Australia, the Americas, and Oceania (Lever 2003; Scalera 2006; Pupins 2007; Kraus 2009; Kikillus et al. 2010; van Dijk et al. 2011; Ficetola et al. 2012; Uetz et al. 2018).

A large number of $T$. scripta elegans are imported into India every year and these turtles have become established in wetlands throughout the nation - including those in Gujarat (Mujpura 2014; Vyas 2015). Because we do not know the nature and extent of any impact this exotic species could have on local fauna, we initiated a series of inquiries regarding this species and began the process of estimating the extent of its distribution in the state of Gujarat and its interactions with native turtles.

We directed inquiries about the species to animal dealers, hobbyists, NGOs, and forest officials of the Gujarat Forest Department and, in the course of herpetofaunal surveys from 2006 to 2016, we recorded 35 observations in bodies of water throughout five biogeographic zones and in 18 of the 33 districts of Gujarat (Fig. 2; Table 1). Bodies of water

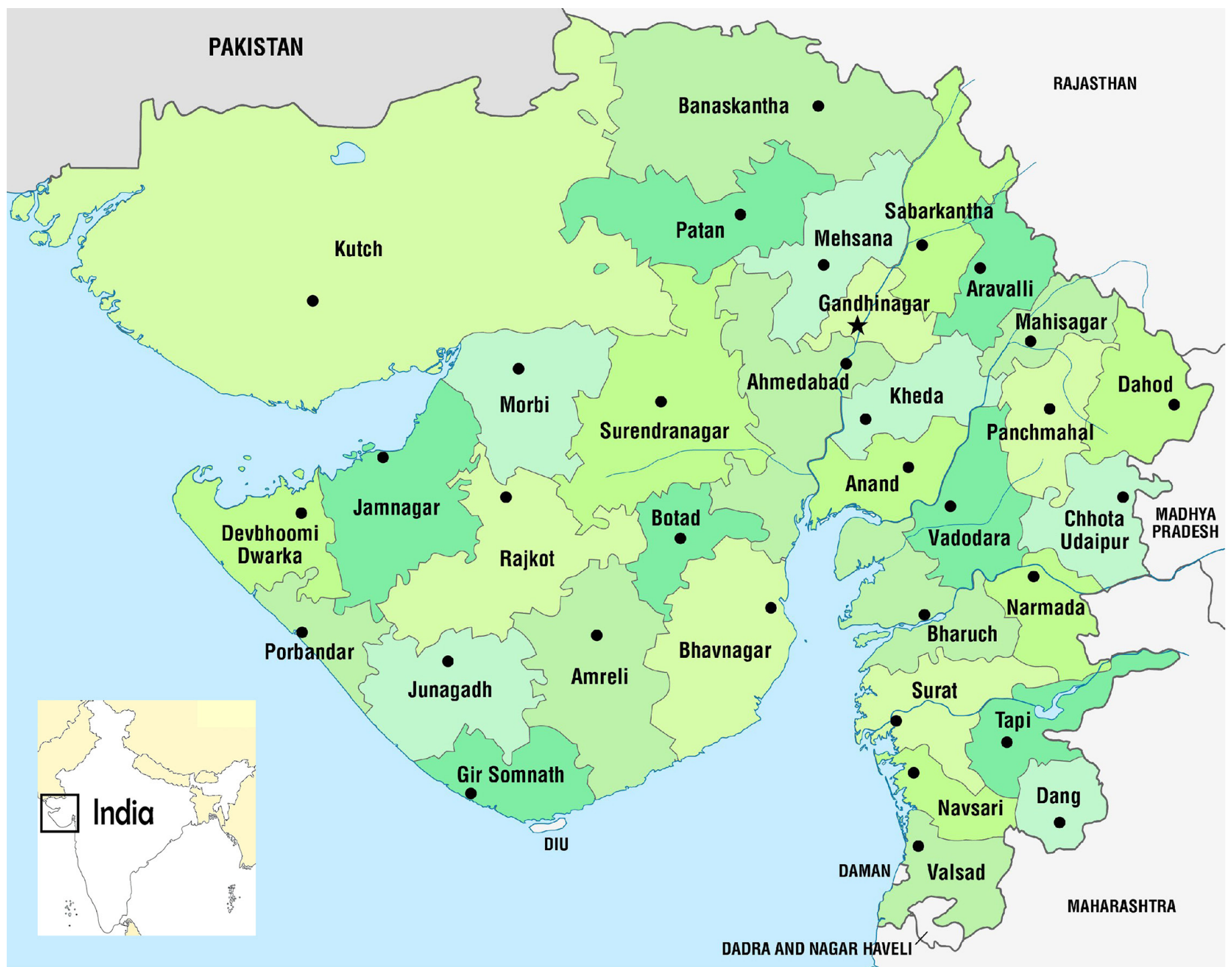

Fig. 2. Map of the state of Gujarat, India, with its administrative districts. 
Table 1. Localities where Red-eared Sliders (Trachemys scripta elegans) occur in Gujarat, India, organized by biogeographic zones (all caps) and districts (bold). Habitats shared with native species are indicated as follows: $\mathrm{LP}=$ Lissemys punctata NG = Nilssonia gangetica PT $=$ Pangshura tecta .

Native

No. Location

Turtle Species

\section{SOUTH GUJARAT}

Valsad District

$1 \quad$ Sukhi Talavadi, Valsad City $20^{\circ} 36$ '26.19”N; 7256'20.27”'E

\section{Tapi District}

2 Jal Vatika, Vyara Town LP

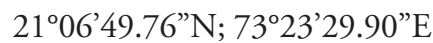

\section{Navsari District}

3 DudhiyaTalav, Navsari City $20^{\circ} 56^{\prime} 51.18^{\prime \prime} \mathrm{N} ; 72^{\circ} 55^{\prime} 35.48^{\prime \prime} \mathrm{E}$

\section{Surat District}

4 Gopi Talav, Surat City LP, NG 2111'18.69”'N; 7249'46.36”'E

5 Tapi River, Nr. Zoo, Surat City LP, NG $21^{\circ} 14^{\prime} 02.90^{\prime \prime} \mathrm{N} ; 72^{\circ} 53^{\prime} 34.85^{\prime \prime} \mathrm{E}$

\section{CENTRAL GUJARAT}

\section{Bharuch District}

$6 \quad$ Ratan Talav, Bharuch City

LP, NG 2141'53.69”'N; 7259'30.91”'E

\section{Vadodara District}

$7 \quad$ Vishwamitri River, New Akota

Bridge, Vadodara City

$22^{\circ} 17^{\prime} 52.43^{\prime \prime} \mathrm{N} ; 73^{\circ} 10^{\prime} 55.66^{\prime \prime} \mathrm{E}$

\begin{tabular}{|c|c|c|}
\hline 8 & $\begin{array}{l}\text { Sama Talav, Sama, Vadodara } \\
22^{\circ} 20^{\prime} 31.98^{\prime} \mathrm{N} ; 73^{\circ} 12^{\prime} 06.70^{\prime} \mathrm{E}\end{array}$ & LP, NG \\
\hline 9 & Lalbaug Talav, Lalbaug, Vadodara & LP, NG \\
\hline & $22^{\circ} 17^{\prime} 02.19^{\prime \prime} \mathrm{N} ; 3^{\circ} 11^{\prime} 48.78 ” \mathrm{E}$ & \\
\hline 10 & Gotri Talaw, Vadodara City & LP, NG \\
\hline & $22^{\circ} 18^{\prime} 51.95^{\prime \prime N} ; 73^{\circ} 08^{\prime} 03.18^{\prime \prime} \mathrm{E}$ & \\
\hline 11 & Harni, Vadodara City & LP, NG \\
\hline & $22^{\circ} 20^{\prime} 18.91 " \mathrm{~N} ; 73^{\circ} 13^{\prime} 09.00^{\prime \prime} \mathrm{E}$ & \\
\hline 12 & Chhani, Vadodara City & LP, NG \\
\hline & $22^{\circ} 21^{\prime} 57.42^{\prime \prime} \mathrm{N} ; 73^{\circ} 10^{\prime} 11.63^{\prime \prime} \mathrm{E}$ & \\
\hline 13 & Sur Sagar, Vadodara City & LP, NG \\
\hline & $22^{\circ} 18^{\prime} 02.73^{\prime \prime N} ; 73^{\circ} 12^{\prime} 13.17^{\prime \prime} \mathrm{E}$ & \\
\hline 14 & Dabhoi Gam Talav, Dabhoi & LP \\
\hline & $22^{\circ} 08^{\prime} 09.77^{\prime \prime} \mathrm{N} ; 73^{\circ} 25^{\prime} 21.46^{\prime \prime} \mathrm{E}$ & \\
\hline & Anand District & \\
\hline 15 & Ambav Sim Talavadi, Ambav, Anand & LP \\
\hline & $22^{\circ} 25^{\prime} 10.04 ” \mathrm{~N} ; 72^{\circ} 59^{\prime 2} 24.96 ” \mathrm{E}$ & \\
\hline & Kheda District & \\
\hline 16 & Kheta Talav, Nadiyad & P, NG, PT \\
\hline & $22^{\circ} 41^{\prime} 27.74 ” \mathrm{~N} ; 72^{\circ} 52^{\prime} 12.31^{\prime \prime} \mathrm{E}$ & \\
\hline
\end{tabular}

17 Gomti Talav, Dakor

LP, NG

$22^{\circ} 45^{\prime} 21.97^{\prime \prime} \mathrm{N}$; 730'ㄱ․ $55^{\prime \prime} \mathrm{E}$

18 Ram Sarovar, Nr. Vaso LP, NG $22^{\circ} 39^{\prime} 03.40$ ” N; 7245'03.03” E

\section{Dahod District}

19 Chhab Talav, Dahod LP

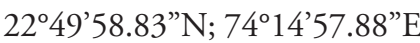

\section{Ahmadabad District}

20 Chandola Lake, Ahmadabad LP, NG, PT 2259'12.62”'N; 72³5'16.08”'E

21 Vastrapur Lake LP $23^{\circ} 02^{\prime} 18.24 " \mathrm{~N} ; 72^{\circ} 31^{\prime} 43.89^{\prime \prime} \mathrm{E}$

22 Pond, Serenity Library, Bhat LP 2306'45.30”N; 72³7’25.26”E

23 Sabarmati River, Nr. Narmada Canal LP, NG, PT $23^{\circ} 07^{\prime} 10.23^{\prime \prime} \mathrm{N}$; 72³9’04.21”E

24 Sarkhej, Ahmadabad LP $22^{\circ} 58^{\prime} 47.41^{\prime \prime} \mathrm{N} ; 72^{\circ} 30^{\prime} 05.06^{\prime \prime} \mathrm{E}$

25 Sanand Town LP, NG 2259'25.02”N; 72²2'55.68”'E

\section{Gandhinagar District}

26 Sabarmati, behind Indroda LP, NG, PT $23^{\circ} 11^{\prime} 39.76^{\prime \prime} \mathrm{N} ; 72^{\circ} 39^{\prime} 44.10^{\prime \prime} \mathrm{E}$

\section{NORTH GUJARAT}

Patan District

27 Anand Sarovar LP

2350’48.81”N; 7207’44.21”E

\section{SAURASHTRA}

Jamnagar District

28 Lakhota Lake, Jamnagar City LP $22^{\circ} 27^{\prime} 54.43^{\prime \prime} \mathrm{N}$; 700.'05.48” E

\section{Bhavanagar District}

29 Krishna Kunj, Victoria Park, Bhavnagar LP $21^{\circ} 45^{\prime} 01.28^{\prime \prime} \mathrm{N} ; 72^{\circ} 07^{\prime} 34.55^{\prime \prime} \mathrm{E}$

30 MotiTalav, New Port Road LP $21^{\circ} 46$ '29.97”N; 72¹0'59.00”'E

\section{Junagadh District}

$31 \quad$ Narshin Mehata Lake LP 2131'07.47”N; 70²7'18.76”'E

\section{Surendranagar District}

32 Dharam Talav LP, NG $22^{\circ} 42^{\prime} 30.71^{\prime \prime} \mathrm{N} ; 71^{\circ} 40^{\prime} 06.70^{\prime \prime} \mathrm{E}$

\begin{tabular}{lll}
\hline & Rajkot District & \\
\hline 33 & Lalpari Lake & LP \\
& $22^{\circ} 18^{\prime} 15.97^{\prime \prime N} ; 70^{\circ} 50^{\prime} 36.05^{\prime \prime} \mathrm{E}$ & \\
\hline 34 & Randarda Lake & LP \\
& $22^{\circ} 17^{\prime 2} 26.56^{\prime \prime N} ; 70^{\circ} 50^{\prime} 32.82^{\prime} \mathrm{E}$ & \\
\hline
\end{tabular}

\section{KUTCH}

Kutch District

35 Hamisar Lake, Bhuj LP $23^{\circ} 15^{\prime} 07.04 ” \mathrm{~N}$; 6939'55.00” E 


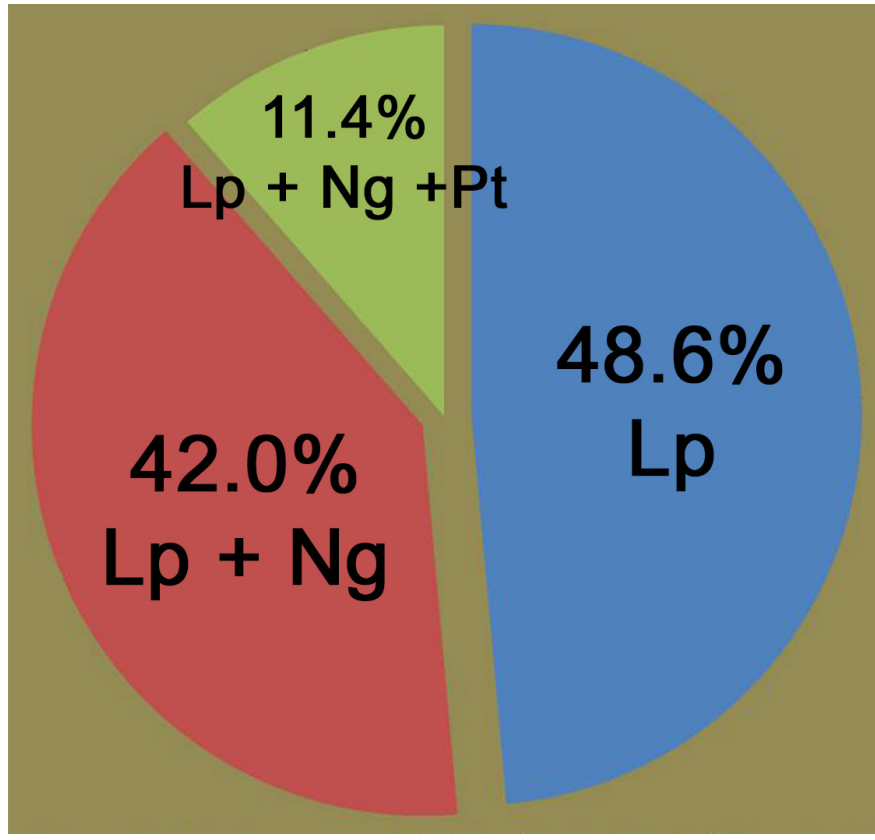

Fig. 3. A pie chart depicting the overlap in the ranges of the invasive Redeared Slider (Trachemys scripta elegans) and three native species of turtles $(\mathrm{Lp}=$ Lissemys punctata $; \mathrm{Ng}=$ Nilssonia gangetica $; \mathrm{Pt}=$ Pangshura tecta $)$ in the state of Gujarat, India.

included village ponds, lakes, and rivers (Tapti, Vishwamitri, Sabarmati). Earlier reports of this species included records from the Malan River, Bhavnagar District (Munjpara 2014) and Gomti tank at Dakor, Anand District (Vyas 2015).

These 35 water bodies are also natural habitats of one or more of three native species of turtles: Indian Roofed Turtle
(Pangshura tecta), Indian Soft-shelled Turtle (Nilssonia ganget$i c a$ ), and Indian Flap-shelled Turtle (Lissemys punctata). The native species sharing habitats with $T$. scripta elegans are indicated in Table 1. Although these species undoubtedly compete for spatial and trophic resources, the nature and extent of the impact of the sliders on the native turtle populations remains unknown and will require further research.

The extensive distribution in Gujarat likely is a consequence of the non-scientific and outdated approaches of inactive authorities who supposedly enforce wildlife laws and conservation practices and a moderately active trade in live animals (mainly for pets; e.g., Vyas 2015, 2017) catering to the many Indians who keep live turtles as pets at home, often in response to increasingly popular "feng-shui" and "vastu shastra" fads. As in Europe (e.g., Cadi and Joly 2004), pets escape or are released in nearby bodies of water without any consideration of the possible consequences. Also, the State Forest Department has been known to confiscate sizeable lots of illegally retained wild animals (including turtles) from individual pet owners, hobbyists, or pet-dealers and then release them into nearby habitats. No guidelines and protocols for the rescue and rehabilitation of confiscated or rescued animals exist. Sadly, in addition to an unwillingness to develop and adopt appropriate protocols, an absence of captive facilities for rescued or confiscated animals contributes to the problem.

Red-eared Sliders were not formally considered an IAS in India (e.g., Choudhury et al. 2000; Mandal 2011) until 2013 (Goenka 2013) and the Wildlife Institute of India, an autonomous institution under the Ministry of Environment

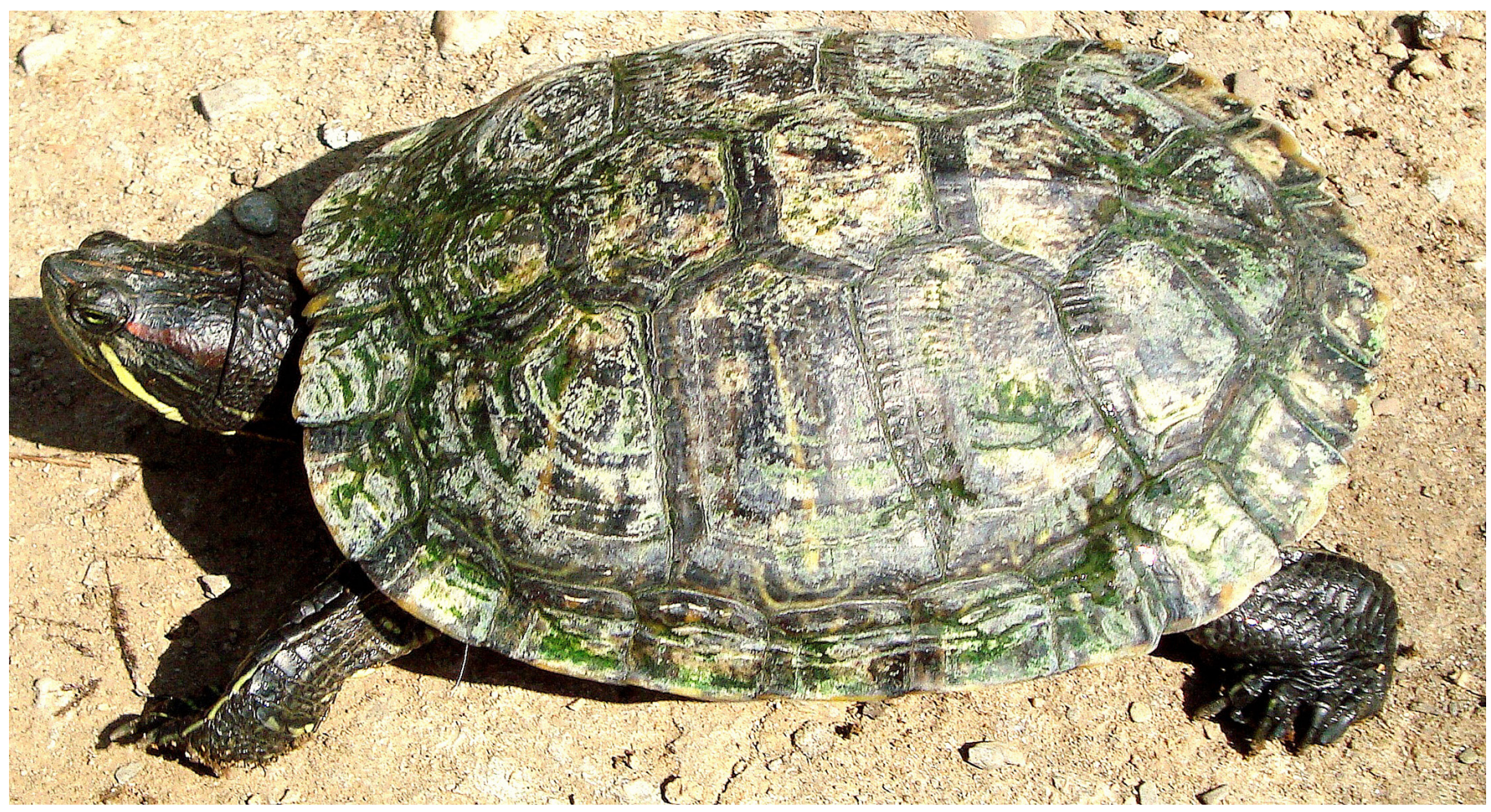

Fig. 4. A Red-eared Slider (Trachemys scripta elegans) from Fatehsagar lake, Udaipur City, Rajasthan, India. Photograph by S.K. Sharma. 
Forest and Climate Change, has yet not addressed this species (e.g., Mathur et al. 2015) despite its documented presence in many Indian states. Published reports include those for Maharashtra (Goenka 2013; Kunju 2014; Telang 2016), temples ponds of Bangalore, Karnataka (Chetan 2013), Himayat Sagar of Hyderabad (Reddy 2016), Dhanas and Sukhna Lakes of Chandigarh (Singh 2015), Rajarhat, Kolkata, West Bengal (Bandyopadhyay 2015; Choudhuri et al. 2018), Fatehsagar Lake (Fig. 3), Udaipur, Rajasthan (S.K. Sharma, pers. comm., 15 December 2016), Goa (Jadav et al. 2018), and now Gujarat. Consequently, determining the severity of the impact of this invasive species on the native fauna and environment should be a high priority. In addition, the potential harm caused by Red-eared Sliders, certainly one of many mostly undocumented IAS, is but one example calling for urgent studies, relevant legislation and policies, and strict legal enforcement to minimize the damage of established IAS and to reduce the likelihood of additional invasions.

\section{Acknowledgements}

I am grateful to Conservator and Deputy Conservator of Forest, Social Forestry, Vadodara Division, Forest Department of Gujarat for supporting this study. I thank all the wildlife enthusiasts and staff of the forest department who helped me in gathering the necessary data, especially Manoj Thaker, Kartik Upadhyay, Nitin Patel, Pravin Maharaj, Nilesh Shah, Rahul Bhatt, Mittal Patel, Raj Bhavsar, Pranav Vaghashiya, Vishal Mistri, Dhaval Patel (Voluntary Nature Conservancy), S.K. Sharma (Rajasthan), and other participants and friends who helped and supported this study.

\section{Literature Cited}

Bandyopadhyay, K. 2015. Exotic turtle found in Rajarhat waterbody. The Times of India, Kolkata. <https://timesofindia.indiatimes.com/city/kolkata/Exoticturtle-found-in-Rajarhat-waterbody/articleshow/48564218.cms>.

Cadi, A. and P. Joly. 2004. Impact of the introduction of the red-eared slider (Trachemys scripta elegans) on survival rates of the European pond turtle (Emys orbicularis). Biodiversity and Conservation 13: 2511-2518.

Chaudhuri, A., A. Banerjee, S. Chowdhury, and K. Deuti. 2018. Report of redeared slider turtle (Trachemys scripta elegans) from a wetland near Kolkata, West Bengal, India. The Herpetological Bulletin 146: 41-42.

Chetan, R. 2013. Water wars reason for turtle deaths. Bangalore Mirror, Bangalore, India. <https://bangaloremirror.indiatimes.com/bangalore/others/IndianPond-Terrapin-Indian-Flapshell-turtles-Dakshinamukha-NanditheerthatempleMalleswarams-Kadu-Malleshwara-temple-BBMP-wildlife/articleshow/26428674.cms>.

Choudhury, B.C., S. Bhupathy, and F. Hanfee. 2000. Status information on the tortoises and freshwater turtles of India, pp. 86-94. In: P.P. van Dijk, B.L. Stuart, and A.G.J. Rhodin (eds.), Asian Turtle Trade: Proceedings of a Workshop on Conservation and Trade of Freshwater Turtles and Tortoises in Asia. Chelonian Research Monographs 2. Chelonian Research Foundation, Lunenburg, Massachusetts.

Drake, J.A., H.A. Mooney, D. Castri, F. Groves, F.J. Kruger, M. Rejmanek, and M. Williamson (eds.). 1989. Biological Invasions: A Global Perspective (SCOPE 37). John Wiley \& Sons, Chichester, England.

Ernst, C.H. and J.E. Lovich. 2009. Turtles of the United States and Canada. 2nd edition. John Hopkins University Press, Baltimore, Maryland.

Ficetola, G.F., D. Rödder, and E. Padoa-Schioppa. 2012. Trachemys scripta (slider terrapin), pp. 331-339. In: R. Francis (ed.), A Handbook of Global Freshwater
Invasive Species. Earthscan, Taylor \& Francis Group, Abingdon, United Kingdom, and New York, New York.

Goenka, K. 2013. There's something fishy going on in Powai lake: Foreign fish making a meal of their native cousins. DNA, Mumbai, India. <https://www. dnaindia.com/mumbai/report-there-s-something-fishy-going-on-in-powailake-foreign-fish-making-a-meal-of-their-native-cousins-1878066>.

IUCN (International Union for Conservation of Nature). 2019. Invasive species. $<$ https://www.iucn.org/theme/species/our-work/invasive-species>.

Jadhav, T.D., N.S. Sawant, and S.K. Shyama. 2018. Diversity and distribution of freshwater turtles (Reptilia: Testudines) in Goa, India. Journal of Threatened Taxa 10: 12194-12202.

Kikillus, K.H., K.M. Hare, and S. Hartley. 2010. Minimizing false-negatives when predicting the potential distribution of an invasive species: A bioclimatic envelope for the red-eared slider at global and regional scales. Animal Conservation 13(suppl. 1): 5-15.

Kraus, F. 2009. Alien Reptiles and Amphibians: A Scientific Compendium and Analysis. Springer, Dordrecht, The Netherlands.

Kunju, S.S. 2014. Indian Flapshell Turtle and Red Eared Slider Turtle rescued at Bhandup. PAWS-Mumbai Press Kit Update, Mumbai, India. <http:// pawsmumbaipresskitupdate.blogspot.com/2014/08/indian-flapshell-turtleand-red-eared.html>.

Lever, C. 2003. Naturalized Reptiles and Amphibians of the World. Oxford University Press, New York, New York.

Lowe, S., M. Browne, S. Boudjelas, and M. De Poorter. 2004. 100 of the World's Worst Invasive Alien Species. A Selection from the Global Invasive Species Database (updated and reprinted version). The Invasive Species Specialist Group (ISSG), Species Survival Commission (SSC), World Conservation Union (IUCN), Gland, Switzerland (first published as a special lift-out in Aliens 12 in December 2000).

Mandal, F.B. 2011.The management of alien species in India. International Journal of Biodiversity and Conservation 3: 467-473.

Mathur, V.B., S.S. Bist, M. Kaushik, N.A. Mungi, and Q. Qureshi. 2015. Management of human wildlife interaction and invasive species in India. Report number TR-2015/004. Wildlife Institute of India, Dehradun.

Munjpara, S. 2014. Will the exotic Red-eared Slider Turtle Trachemys scripta elegans become invasive in India? Jalaplavit 5(2): 47-48.

Ng, P.K.A., O'Riordan, R.M., Ramsay, N.F. and L.M. Chou. 2005. Are redeared sliders reproducing in Singapore? [Abstract], p. 77. In: Abstracts and Programme. Fifth World Congress of Herpetology. Stellenbosch, South Africa.

Pande, H.K. and S. Arora (eds.). 2014. India's Fifth National Report to the Convention on Biological Diversity. Ministry of Environment and Forests, Government of India, New Delhi.

Powell, R., R. Conant, and J.T. Collins. 2016. Peterson Field Guide to Reptiles and Amphibians of Eastern and Central North America. 4th edition. Houghton Mifflin Harcourt, Boston, Massachusetts.

Pupins, M. 2007. First report on recording of the invasive species Trachemys scripta elegans, a potential competitor of Emys orbicularis in Latvia. Acta Universitatis Latviensis 723, Biology: 37-46.

Ramsay, N.F., P.K.A. Ng, R.M. O'Riordan, and L.M. Chou. 2007. The redeared slider (Trachemys scripta elegans) in Asia: a review, pp. 161-174. In: F. Gherardi (ed.), Biological Invaders in Inland Waters: Profiles, Distribution, and Threats. Springer, Dordrecht, The Netherlands.

Ramkrishnan, P.S. (ed.). 1991. Ecology of Biological Invasion in the Tropics. National Institute of Ecology, Jaipur, India.

Reddy, U.S. 2016. Red-eared turtle takes over lakes. Deccan Chronicle, Hyderabad, India. <https://www.deccanchronicle.com/lifestyle/pets-and-environment/071116/red-eared-turtle-takes-over-lakes.html>.

Rhodin, A.G.J. and J.L. Carr. 2009. A quarter millenium of uses and misuses of the turtle name Testudo scabra: Identification of the type specimens of $T$. scabra Linnaeus 1758 (= Rhinoclemmys punctularia) and T. scripta Thunberg in Schoepff 1792 (= Trachemys scripta scripta). Zootaxa 2226: 1-18.

Scalera, R. 2006. Trachemys scripta. DAISIE (Delivering Alien Invasive Species Inventories for Europe). <http://www.europe-aliens.org/pdf/Trachemys_scripta.pdfs.

Singh, V.J. 2015. Wildbuzz: Born not to be free. Hindustan Times, New Delhi, India. <https://www.hindustantimes.com/chandigarh/wildbuzz-born-not-tobe-free/story-oRWPyUJeAdckQ1JvoxgGIJ.html>.

Telang, S. 2016. Turtle tidings. The Afternoon Despatch \& Courier, Mumbai, India. $<$ http://www.afternoondc.in/city-news/turtle-tidings/article_173754>. 
Uetz, P., P. Freed, and J. Hošek (eds.). 2018. The Reptile Database <http://www. reptile-database.org>.

van Dijk, P.P., J. Harding, and G.A. Hammerson. 2011. Trachemys scripta (errata version published in 2016). The IUCN Red List of Threatened Species 2011: e.T22028A97429935. <http://dx.doi.org/10.2305/IUCN.UK.2011-1. RLTS.T22028A9347395.en>.
Vyas, R. 2015. Status of Ganges Soft-shell Turtle (Nilssonia gangetica) amidst deplorable scenarios in urban wetlands of central Gujarat State, India. Reptile Rap 17: 3-12.

Vyas, R. 2017. A Northern River Terrapin (Batagur baska) from Kutch, with comments on the species' distribution in western India and Pakistan. Reptiles \& Amphibians 24: $128-131$. 